\title{
Hubungan Kadar Interleukin-10 Serum dan Kadar Leukosit Darah Perifer pada Pasien Cedera Otak Berat Akibat Trauma
}

\author{
${ }^{1}$ Edih Suyanto, ${ }^{2}$ Eko Prasetyo, ${ }^{2}$ Maximillian Ch. Oley \\ ${ }^{1}$ PPDS Ilmu Bedah Fakultas Kedokteran Universitas Sam Ratulangi Manado \\ ${ }^{2}$ Divisi Bedah Saraf Bagian Ilmu Bedah Fakultas Kedokteran Universitas Sam Ratulangi \\ RSUP Prof. Dr. R. D. KandouManado \\ Email: edih_suyanto@yahoo.com
}

\begin{abstract}
This study was aimed to prove that in severe traumatic brain injury (TBI) there was an elevation in serum IL-10 level as well as in peripheral blood leukocyte level, and a correlation between both of them. This was an analytical correlational study. All patients had IL-10 level above normal value $(18 \mathrm{pg} / \mathrm{ml})$. There were three patients with normal blood leukocyte level. The correlation between IL-10 and blood leukocyte level was tested by using simple linear regression analysis and Pearson correlation coefficient analysis which obtained $\mathrm{r}$ $=0.045$ with a $P$ of $0.426(>0.05)$. These results indicated a positive relationship between IL10 and leukocytes levels, but not statistically significant. Conclusion: Interleukin-10 was consistantly elevated following severe traumatic brain injury and was a better TBI biomarker than the peripheral leukocyte level.
\end{abstract}

Keywords: IL-10, leukocytes, TBI

\begin{abstract}
Abstrak: Penelitian ini bertujuan untuk membuktikan bahwa pada cedera otak akibat trauma (COT) berat terdapat peningkatan kadar serum IL-10 dan kadar leukosit darah perifer serta korelasi antara keduanya. Jenis penelitian ini ialah analitik korelasional. Hasil penelitian mendapatkan 20 pasien dengan COT berat berusia 16-65 tahun. Semua pasien memperlihatkan kadar Il-10 di atas nilai normal $(18 \mathrm{pg} / \mathrm{ml})$. Terdapat 3 pasien dengan kadar leukosit dalam batas normal Hubungan antara IL-10 dan leukosit diuji dengan analisis regresi linier sederhana dan analisis koefisien korelasi Pearson dan mendapatkan $r=0,045$ dengan $P=0,426$. Hasil ini menunjukkan hubungan positif antara IL-10 dan leukosit, tetapi tidak bermakna secara statistik $(P=0,426>0,05)$. Simpulan: IL-10 secara konsisten meningkat setelah COT dan sebagai biomarker COT yang lebih baik daripada leukosit perifer.
\end{abstract}

Kata kunci: IL-10, leukosit, COT

Cedera otak akibat trauma (COT) merupakan cedera yang terjadi karena adanya tekanan mekanik eksternal yang mengenai kranium dan komponen intrakranial sehingga menimbulkan kerusakan sementara atau permanen pada otak, gangguan fungsional, atau gangguan psikososial.

Angka kejadian COT meningkat setiap tahun terutama karena kecelakaan lalu lintas di negara berkembang. Di Amerika Serikat didapatkan 2,5 juta pasien per tahun yang datang ke unit gawat darurat arena
COT, sekitar $87 \% \quad(2.213 .826)$ telah diobati, dan $11 \%$ (283.630) dirawat dan keluar rumah sakit, dan 2\% (52.844) meninggal. ${ }^{1}$ Data epidemiologi COT di Indonesia sendiri belum tersedia secara nasional. Data RSUP Prof. Dr. R. D. Kandou Manado periode 2012-2013 memperlihatkan 206 pasien dengan cedera kepala. Sebanyak 105 pasien mengalami cedera kepala ringan, 64 pasien mengalami cedera kepala sedang, dan 37 pasien mengalami cedera kepala berat. ${ }^{2}$ 
Inflamasi setelah cedera otak berat dapat menyebabkan komplikasi yang dapat memengaruhi outcome pasien termasuk sindrom respon inflamasi sitemik. Sindrom klinis ini merupakan hasil dari perluasan aktifitas jalur inflamatorik. Proses inflamasi yang teraktivasi setelah cedera otak berat dimediasi oleh pelepasan sitokin pre dan anti-inflamasi. Sitokin-sitokin ini merupakan polipeptida yang jarang diobservasi pada otak yang sehat tetapi kadarnya meningkat dengan cepat sebagai respons kondisi patologik atau penuh tekanan. Terdapat tipe sitokin yang berbeda-beda termasuk interleukin pada penyakit sistem saraf tepi dan pusat seperti syok, meningitis, dan cedera kepala. Perkembangan pada pemaham cedera sekunder menghasilkan intervensi terapeutik untuk mencegah kerusakan jaringan yang progresif dan gangguan fungsi setelahnya. ${ }^{3}$

Sitokin merupakan mediator penting dari neuroinflamasi setelah terjadi cedera otak, berfungsi mengatur fungsi seluler yang luas dan bervariasi melalui jaringan sinyal autokrin dan parakrin yang mengatur patologi imun yang tidak terkendali. Peningkatan sintesis dan pelepasan sitokin pro dan anti inflamasi ke dalam susanan saraf pusat dan darah dikaitkan dengan cedera otak berat. Pada hewan model, sebagai contoh, induksi TNF- $\alpha$ dan IL- $1 \beta$ memuncak di awal dalam waktu 3-8 jam setelah cedera, diikuti oleh peningkatan IL6, dan IL-10 berkepanjangan. Sitokin TNF$\alpha$ dan IL-10 diproduksi dalam konsentrasi yang tinggi oleh populasi mikroglia dan infiltrasi monosit/makrofag pada cedera fase akut. Reaktivasi astrosit yang distimulasi oleh sitokin inflamatorik memberikan kontribusi terhadap peningkatan neuroinflamasi dan perkembangan cedera sekunder yang terjadi setelah neurotrauma. ${ }^{4}$ Sitokin IL-10 sebagai anti apoptosis dan proliferasi terhadap sel yang tidak aktif secara langsung dapat meningkatkan kelangsungan hidup dari neuron kortikal dan neuron serebelum serta astrosit, sel glia, dan oligodendrosit dari apoptosis dengan menghambat kematian apoptosis pada tingkat mitokondria. Tingkat kesa- daran merupakan komponen penting dalam pemeriksaan neurologik. Penilaian sistemik pada pasien yang tidak sadar dengan menerapkan GCS sebagai skala numerik dapat memberikan informasi prognostik. ${ }^{5}$

Trauma kepala dikaitkan dengan respon fase akut yaitu adanya leukositosis karena kenaikan kadar katekolamin dan kortisol. Terbentuknya edema dini setelah cedera kepala berat juga terjadi dengan mengaktivasi mikroglia. Oleh karena itu, peningkatan leukosit yang dihitung setelah trauma kepala dapat menjadi parameter prediktif dari tingkat keparahan suatu trauma kranioserebral. ${ }^{6}$

Meskipun inflamasi akut berperan penting terhadap fisiologi otak, hubungan khusus antara mediator inflamasi setelah cedera otak berat belum sepenuhnya dipahami. Penelitian ini bertujuan untuk mendapatkan hubungan antara kadar serum IL-10 dan kadar leukosit darah perifer pada pasien COT berat yang dapat menambah wawasan dalam tatalaksana protektif yang efektif pada pasien cedera otak berat, pemahaman selular yang kompleks, dan kejadian di tingkat molekular.

\section{METODE PENELITIAN}

Jenis penelitian ini ialah analitik korelasional untuk menganalisis hubungan kadar IL-10 serum dan kadar leukosit darah perifer pada pasien COT berat. Penelitian ini dilakukan di RSUP Prof. Dr. R. D. Kandou Manado dan dimulai sejak November 2017 hingga jumlah sampel tercukupi.

Data yang diperoleh diolah melalui program SPSS serta dilakukan analisis univariat dan bivariat pada batas kemaknaan $\alpha=5 \%$. Untuk hubungan antara perubahan kadar serum IL-10 dan kadar leukosit darah perifer pada COT berat digunakan analisis regresi sederhana dan analisis koefisien korelasi Pearson.

\section{HASIL PENELITIAN}

Penelitian ini dilakukan pada bulan November 2017 s/d Januari 2018 dan diperoleh subjek penelitian sebanyak 20 orang yang memenuhi kriteria inklusi, terdiri dari 17 orang laki-laki $(85 \%)$ dan 3 
orang perempuan (15\%). Hal tersebut mengasumsikan bahwa laki-laki lebih aktif di luar rumah dibandingkan perempuan. Usia subyek penelitian berkisar antara 16 sampai 59 tahun dengan rerata 34,10 tahun (SD $\pm 13,014$ tahun) yang sesuai dengan karakter usia produktif. Pada semua subjek penelitian dilakukan pemeriksaan dan penanganan di IRDB RSUP Prof. Dr. R. D. Kandou sesuai dengan ATLS.

Tabel 1 memperlihatkan bahwa kadar IL-10 serum terendah ialah $73,15 \mathrm{pg} / \mathrm{ml}$ dan tertinggi $132,02 \mathrm{pg} / \mathrm{ml}$. Kadar Il-10 pada seluruh subyek lebih tinggi daripada kadar Il-10 normal, yaitu <18 pg untuk kedua jenis kelamin dan semua kelompok usia. $^{7}$

Kadar leukosit terendah yaitu $9400 / \mu \mathrm{L}$ dan tertinggi 38700/ $\mu \mathrm{L}$. Terdapat 3 subyek dengan kadar leukosit dalam batas normal; sisanya mengalami peningkatan kadar leukosit.

Tabel 1. Karakteristik kadar IL-10 serum dan hitung leukosit pada subyek penelitian

\begin{tabular}{lcc}
\hline & IL-10 & $\begin{array}{c}\text { Kadar } \\
\text { leukosit }\end{array}$ \\
\hline $\mathrm{N}$ & 20 & 20 \\
Minimum & 73,15 & 9400 \\
Maksimum & 132,02 & 38700 \\
Rerata & 105,7080 & 22533,25 \\
Std Deviasi & 0,099772 & 8116,490 \\
\hline
\end{tabular}

Hubungan antara IL-10 dan leukosit diuji dengan analisis regresi linear sederhana dan analisis koefisien korelasi Pearson dan diperoleh $\mathrm{r}=0,045$ dengan $P$ $=0,426$. Hasil ini menyatakan terdapat hubungan positif antara IL-10 dan leukosit, namun secara statistik tidak bermakna $(P=$ $0,426>0,05)$. Secara grafik hubungan kedua variabel dapat dilihat pada Gambar 1.

\section{BAHASAN}

Pada penelitian ini didapatkan sebanyak 20 subjek yang memenuhi kreteria inklusi dan diikut sertakan dalam penelitian. Hasil penelitian menunjukkan bahwa subyek berjenis kelamin laki-laki lebih banyak daripada perempuan, berusia 16-65

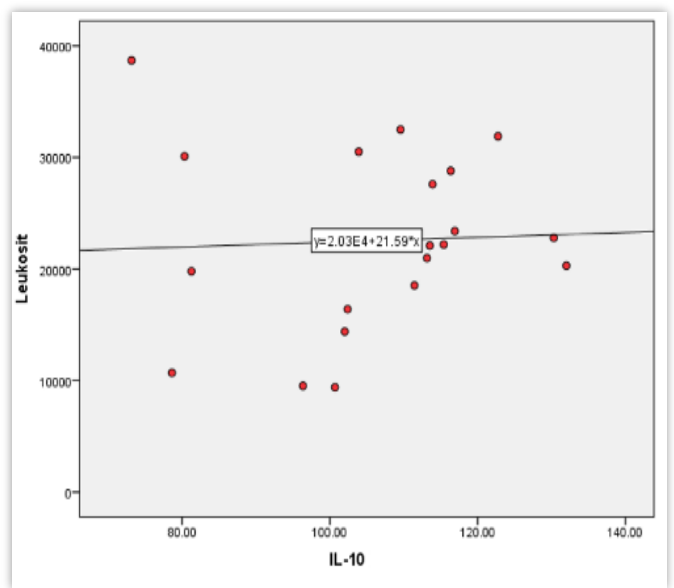

Gambar 1. Hubungan IL-10 dengan leukosit pada pasien cedera otak berat akibat trauma

tahun, dan waktu datang onset ke rumah sakit <24 jam setelah kejadian.

Pengukuran kadar IL-10 secara statistik menunjukkan korelasi bermakna pada cedera otak berat yang ditentukan oleh Glasgow Coma Scale (GCS). Hasil ini sesuai dengan temuan sebelumnya yang menunjukkan bahwa IL-10 diproduksi cepat setelah cedera otak. Bukti tersebut menunjukkan tingkat keparahan cedera otak yang berkorelasi dengan sitokin antiinflamasi setelah cedera otak. Pasien dengan kadar serum IL-10 $<50 \mathrm{pg} / \mathrm{ml}$, secara bermakna menunjukkan ketahanan hidup lebih besar dibandingkan pasien dengan kadar serum yang lebih tinggi $(P$ $<0.01)$. Pasien dengan kadar serum IL-10 $>90 \mathrm{pg} / \mathrm{ml}$ setelah 30 jam pada cedera otak berat, berisiko dua kali lebih sering terkait dengan kematian daripada yang dengan kadar serum lebih rendah. ${ }^{4}$

Pada penelitian ini kadar serum IL-10 terendah ialah $73,15 \mathrm{pg} / \mathrm{ml}$, dan tertinggi yaitu 132,02 $\mathrm{pg} / \mathrm{ml}$ dengan rerata 105,70 $\mathrm{pg} / \mathrm{ml}$. Kadar IL-10 meningkat dalam 24 jam pertama setelah cedera otak berat. Hal ini sesuai dengan penelitian Gracia et al. ${ }^{8}$ melaporkan bahwa ekspresi IL-10 meningkat dalam 24 jam pertama setelah trauma kepala berat, dan konsisten dengan sifat anti-inflamasi, peningkatan IL-10 telah dilaporkan sesuai dengan penurunan tingkat TNF.

Potensi prognostik IL-10 memiliki 
kegunaan paling banyak dalam memrediksi angka kematian setelah COT, meski masih kontroversial dalam berbagai literatur. Oleh karena itu tugas di masa depan diperlukan untuk menentukan peran IL-10 dalam memrediksi hasil lainnya. ${ }^{8}$

Sun et al. ${ }^{9}$ menyatakan bahwa jumlah leukosit yang meningkat bernilai prediktif terhadap kerusakan neurologik. Data penelitian menunjukkan peradangan yang meningkat setelah perdarahan intraserebral terkait dengan kerusakan awal neurologik.

Respons inflamasi, aktivasi sel endotel, dan pelepasan mediator inflamasi pada cedera kepala dapat meningkatkan jumlah leukosit. Cedera kepala berhubungan dengan respons fase akut yang ditandai dengan leukositosis akibat meningkatnya epinefrin dan kortisol. ${ }^{10}$

Pada cedera otak terjadi ruptur traumatik mikrovaskuler yang akan diikuti dengan terjadinya oklusi fisik. Sifat leukosit sukar berubah bentuk bila dibandingkan dengan eritrosit, sehingga dibutuhkan tekanan lebih besar agar leukosit dapat melewati pembuluh darah kapiler yang berdiameter kecil. Pada keadaan dimana perfusi jaringan turun, kapiler berfungsi sebagai filter yang menyaring lekosit sehingga terjadi peningkatan leukosit di darah tepi. Setelah terperangkap di kapiler, terjadi adhesi leukosit dengan endotel sehingga leukosit tidak akan terlepas walau tekanan perfusi kembali normal. ${ }^{11}$ Pada penelitian ini nilai rerata kadar leukosit darah perifer yaitu $22,5 \times 10^{3} / \mu \mathrm{L}$. Jumlah leukosit yang melebihi $17,5 \times 10^{6} / \mathrm{L}$ memiliki nilai prediktif untuk skor GCS yang buruk dan lama tinggal di rumah sakit. ${ }^{6}$

Menurut Polapa et al. ${ }^{12}$ peningkatan total kadar leukosit darah perifer pada cedera otak risiko tinggi dengan rerata pemeriksaan kadar total lekosit perifer awal $20,6 x \cdot 10^{3} / \mu \mathrm{L}$; rerata kadar lekosit 24 jam pasca trauma $22,4 \times 10^{3} / \mu \mathrm{L}$; dan rerata kadar lekosit 48 jam pasca trauma $24,8 \times 10^{3}$ $/ \mu \mathrm{L}$. Peningkatan leukosit terjadi secara bermakna pada awal 3 jam setelah cedera otak, ${ }^{13}$ dan leukosit polimorfonuklear akan terakumulasi sampai 48 jam pasca trauma. ${ }^{14}$
Pada penelitian ini kadar serum IL-10 dan leukosit diuji dengan analisis regresi linear sederhana dan analisis koefisien korelasi Pearson dan diperoleh $\mathrm{r}=0,045$ dengan $P=0,426(P>0,05)$. Hasil ini menyatakan adanya hubungan positif antara IL-10 dan leukosit, namun secara statistik tidak bermakna.

Interleukin-10 sebagai faktor penghambat sintesis sitokin dan dapat melemahkan sintesis sitokin proinflamasi, IL-10 juga membatasi reaksi peradangan dengan mengurangi ekspresi reseptor sitokin dan menghambat aktivasi reseptor. Selanjutnya, IL-10 mempunyai efek ampuh dan beragam pada semua sel hematopoetik, yang menginfiltrasi ke otak setelah cedera. Sebagai contoh, IL-10 mengurangi fungsi aktivasi dan efektor sel T, monosit, dan makrofag, akhirnya mengakhiri respons inflamasi cedera. $^{8}$

\section{SIMPULAN}

IL-10 meningkat secara konsisten setelah cedera otak akibat trauma dan dapat digunakan sebagai biomarker cedera otak akibat trauma yang lebih baik daripada kadar leukosit perifer.

\section{DAFTAR PUSTAKA}

1. Friede TR, Houry D, Baldwin G. Centers for Disease Control and Prevention. Report to Congress on Traumatic Brain Injury in the United States: Epidemiology and Rehabilitation. National Center for Injury Prevention and Control; Division of Unintentional Injury Prevention. Atlanta, GA. 2015; p. 2.

2. Manarisip MEI, Oley MCh, Limpeleh H. Gambaran CT scan kepala pada penderita cedera kepala ringan di BLU RSUP Prof. Dr. R. D. Kandou Manado periode 2012-2013. eCl. 2014;2(2).

3. Yousefzadeh-Chabok S, Moghaddam AD, Kazemnejad-Leili E, Saneei Z, Hosseinpour M, KouchakinejadEramsadati L, et al. The relationship between serum levels of interleukins 6 , 8,10 and clinical outcome in patients with severe traumatic brain injury. Arch Trauma Res. 2015;4(1):e18357.

4. Schneider SFM, Menezes de Souza N, Liborio SM, Pajm DA, Costa NJ, 
Hohl A, et al. Interleukin-10 is an independent biomarker of severe traumatic brain injury prognosis. Neuroimmunomodulation. 2012;19(6): 377-85.

5. Sabir S, Umer N, Shoaib M, Zulfiqar S. Correlation of interleukin-10 with Glasgow coma scale in patients of stroke. PJMHS. 2016;10(1):63-5.

6. Gürkanlar D, Lakadmyali H, Erguin T, Yilmaz C, Yucel E, Altinors N. Predictive value of leukocytosis in head trauma. Turkish Neurosurgery. 2009; 19(3):211-5.

7. The normal result for IL-10 for interleukin 10 is $<18 \mathrm{pg} / \mathrm{ml}$ for unisex gender and for all age groups. Available from: https://www.practo.com/tests/interleuki n-10-quantitative-multiplex-beadassay-blood/p

8. Garcia JM, Stilings SA, Leclerc JL, Philips H, Edwards NJ, Robicsek SA, et al. The role of interleukin-10 in acute brain injury. Front Neurol. 2017;8:244.

9. Sun W, Peacock A, Becker J, Philips-Bute B, Laskowitz DT,James ML, et al. Correlation of leukocytosis with early neurological deterioration following supratentorial intracerebral hemorrhage. J Clin Neurosci. 2012;19(8):
1096-100.

10. Norton JA, Barie PS, Bollinger RR, Chang AE, Lowry SF, Mulvihill S, et al. Traumatic Brain Injury. Surgery Basic Science and Clinical Evidence (2nd ed). New York: Springer, 2008; p. 461.

11. Logsdon AF, Lucke-Wold BP, Turner RC, Huber JD, Rosen CL, Simpkins JW. Role of microvascular disruption in brain damage from traumatic brain injury. Compr Physio. 2015;5(3):114760.

12. Polapa M, Prasetyo E, Oley M. Hubungan antara dinamika suhu tubuh dan leukosit perifer dengan skala skor FOUR penderita cedera otak risiko tinggi. JBM. 2016;8(3):179-83.

13. Hazeldine J, Janet Lord M, Belli A. Traumatic brain injury and peripheral immune suppression: primer and prospectus. Front Neurol. 2015;6:235.

14. Biagas KV, Uhl MW, Schiding JK, Nemoto EJ, Kochanek PM. Assessment of posttraumatic polymorphonuclear leucocyte accumulation in rat brain using tissue myeloperoxidase assay and vinblastine treatment. J Neurotrauma. 1992;9(4): 363-71. 